\title{
High-Resolution Strain Monitoring During $M>2$ Events in a South African Deep Gold Mine in Close Proximity to Hypocentres
}

\author{
H. Ogasawara, J. Takeuchi, N. Shimoda Faculty of Science and Engineering, Ritsumeikan University, Japan \\ H. Ishi Tono Research Institute of Earthquake Science, Japan \\ S. Nakao Faculty of Science, Kagoshima University, Japan \\ G. van Aswegen, A.J. Mendecki, A. Cichowicz ISS International Ltd, South Africa \\ R. Ebrahim-Trollope GeoHydroSeis, South Africa \\ H. Kawakata, Y. lio Disaster Prevention Research Institute, Kyoto University, Japan \\ T. Ohkura Graduate School of Science, Kyoto University, Japan \\ M. Ando Graduate School of Environmental Studies, Nagoya University, Japan
}

The Research Group for Semi-Controlled Earthquake-Generation Experiments in South African deep gold mines

The authors document strain changes up to $\sim 10^{-4}$ associated with two $M>2$ events $2.4 \mathrm{~km}$ deep at distances less than $\sim 100 \mathrm{~m}$ from a strainmeter. This corresponds to a $\sim 7 \mathrm{MPa}$ stress change recorded only within the hypocentral area. This change was recorded with a sensitive, wide-dynamic-range, Ishii strainmeter. A 15-m hole was drilled subparallel to the fault strike, in order to continuously monitor slip-driving shear and normal strains with a sampling frequency of $25 \mathrm{~Hz}$. Two $M>2$ events took place around the fault. For both events, relaxation in the maximum principal stress at a rate of 10 -6 /week was observed for several days prior to the main shock. In one of the two events, foreshocks were concentrated in the last several tens of seconds, accompanied by strain steps and logarithmic post-seismic deformation. However, no acceleration in deformation was observed, even with a resolution of 1/10,000 of a coseismic step for each event.

\section{INTRODUCTION}

Despite developments in modern technology, it is still a major challenge to monitor earthquake sources in Japan, because great earthquakes $(M>7)$ occur infrequently and are often far from monitoring stations. Even with the highest sensitivity instruments or GPS, the best resolution of strain transients is poorer than $1 / 1,000$ of a co-seismic step if we rely on surface monitoring (e.g. Johnston, 2002). To overcome this problem, pioneering work was done monitoring an earthquake in close proximity to South African gold mines by the McGarr group in the 1970s and 1980s (e.g. McGarr 1976, McGarr and Green 1975, 1978, McGarr et al., 1982). The work has been referred to by Nicolaysen (1992) as semi-controlled earthquakegeneration experiments. With the use of modern technology developed in Japan (e.g. Ishii et al., 1997a, 2002) and by ISS International (e.g. Mendecki 1993, 1997), Japanese and South African seismologists have been collaborating since 1992 to understand the entire life span of an earthquake (Sumitomo 1998, Iio and Fukao 1992, Iio 1995, Ogasawara et al., 2002).

As the second phase in our study, we installed a sensitive, stable and robust strainmeter in a potential seismic source area at the Bambanani mine, Welkom, South Africa. We then successfully monitored the entire life spans of two $M>2$ events and associated seismic activities, as documented herein.

\section{EXPERIMENTAL SITE AND MONITORING}

\subsection{Experimental Site}

Our experimental site is located at a fault-loss (a loss of gold reef caused by a geological normal fault; Figure 1) at a depth of $2.4 \mathrm{~km}$. Figure 1 schematically illustrates the geology, access tunnels and strainmeter configuration at this site. The reef dips 35 degree to the east-southeast and is offset by several faults with throws of several tens of metres and with nearly the same strike as the gold reef. Multiple horizontal crosscut tunnels were excavated parallel with each other and orthogonal to the strikes of the faults and the reef, with an average tunnel spacing of about $200 \mathrm{~m}$ horizontally and about



FIG. 1 Schematic illustration showing geology, access tunnels and strainmeter (diamond) in a vertical section perpendicular to strikes of the faults and thin, tabular gold reefs

200 feet vertically. Around our experimental site, the western side of the reef experienced an M3.4 event in 1998. Significant seismicity was anticipated in association with further mining of the eastern side of the reef, and significant seismicity did take place within about $100 \mathrm{~m}$ of the strainmeter. The largest events were M3.5, 2.7, 2.5 and 2.4, as detailed herein.

\subsection{Strainmeter and Strain Monitoring}

Usual strain (or stress) monitoring in mines is carried out with e.g. strain cells such as a doorstopper or a CSIR cell (e.g. Amadei and Stephansson, 1997). Ryder and Jager (2002) also review some other related techniques used in hard rock mines. Most techniques can accommodate strain changes larger than $10^{-3}$, but resolutions are no better than $10^{-6}$.

Pioneering, sensitive strain-monitoring in South African mines was carried out by McGarr et al. (1982) with the Sacks- 
TABLE 1 Comparison of related projects of sensitive strain monitoring

\begin{tabular}{|c|c|c|c|c|}
\hline $\begin{array}{l}\text { Mine/ } \\
\text { Site generation }\end{array}$ & EPRM & $\begin{array}{l}\text { Western Holdings/ } \\
\text { Our pilot site }\end{array}$ & WDL/Our 1st site & $\begin{array}{l}\text { Bambanani/Our 2nd site } \\
\text { (this study) }\end{array}$ \\
\hline References & McGarr (1982) & $\begin{array}{l}\text { Ishii et al. (1996) } \\
\text { Eden (1995) } \\
\text { Ogasawara et al. (2002) }\end{array}$ & $\begin{array}{l}\text { Ishii et al. }(1997 b, 1998) \\
\text { Ogasawara et al. } \\
(2001,2002)\end{array}$ & $\begin{array}{l}\text { Ishii et al. (2000) } \\
\text { Ogasawara et al. } \\
(1999,2001,2002)\end{array}$ \\
\hline \multicolumn{5}{|l|}{ Instruments } \\
\hline type & Sacks-Evertson & Ishii & Ishii & Ishii \\
\hline quantity & 3 & 1 & 4 & 1 \\
\hline component & Only dilatation & 3 & 3 & 4 \\
\hline sensitivity & $1 \mathrm{E}-9$ & $1 \mathrm{E}-9$ & $1 \mathrm{E}-9$ & $1 \mathrm{E}-9$ \\
\hline dynamic range & $5 \mathrm{E}-6$ & $2 \mathrm{E}-4$ & $7.5 \mathrm{E}-4$ & $7.5 \mathrm{E}-4$ \\
\hline diameter & $114 \mathrm{~mm}$ & $66 \mathrm{~mm}$ & $66 \mathrm{~mm}$ & $66 \mathrm{~mm}$ \\
\hline length & $1.5 \mathrm{~m}$ & $1.1 \mathrm{~m}$ & $1.1 \mathrm{~m}$ & $1.3 \mathrm{~m}$ \\
\hline \multicolumn{5}{|l|}{ Hole } \\
\hline diameter & $141 \mathrm{~mm}$ & $92 \mathrm{~mm}$ & $92 \mathrm{~mm}$ & $92 \mathrm{~mm}$ \\
\hline length & $6-7 \mathrm{~m}$ & $10 \mathrm{~m}$ & $10 \mathrm{~m}$ & $15 \mathrm{~m}$ \\
\hline \multicolumn{5}{|l|}{ Monitoring } \\
\hline intermission & Everyday for zeroing & $\begin{array}{l}\text { Only on a failure in power } \\
\text { or communication }\end{array}$ & $\begin{array}{l}\text { Only on a failure in power } \\
\text { or communication }\end{array}$ & $\begin{array}{l}\text { Only on a failure in power } \\
\text { or communication }\end{array}$ \\
\hline sampling period & $4 \mathrm{~s}$ & 15 minute & 15 minute & 0.04 second \\
\hline recording & Paper or magnetic tape & Digital & Digital & Digital \\
\hline resolution & $8 \mathrm{E}-9 / \mathrm{mm}$ & $\begin{array}{l}\text { 12-bit } A / D \\
\text { with manual zeroing }\end{array}$ & 12-bit A/D & 24-bit A/D \\
\hline Site & $\sim 3 \mathrm{~km}$ deep & $\sim 1.5 \mathrm{~km}$ deep & $\sim 2.6 \mathrm{~km}$ deep & $\sim 2.4 \mathrm{~km}$ deep \\
\hline location & Above advancing face & $\begin{array}{l}\text { At a dyke adjacent } \\
\text { to mining }\end{array}$ & Beneath advancing face & At a fault-loss \\
\hline $\begin{array}{l}\text { geological } \\
\text { feature }\end{array}$ & No faults documented & Dyke & No faults & $\sim 100 \mathrm{~m}$ fault \\
\hline \multicolumn{5}{|l|}{ Close event } \\
\hline magnitude & $\operatorname{Max} 3.7$ & $>0$ & $\operatorname{Max} 2.0$ & $\operatorname{Max} 3.5$ \\
\hline distance & $\sim 100 \mathrm{~m}$ & $<75 \mathrm{~m}$ & $\sim 100 \mathrm{~m}$ & $\sim 100 \mathrm{~m}$ \\
\hline \multicolumn{5}{|l|}{ Strain change } \\
\hline Long-term & Unable to record & $\sim 1 \mathrm{E}-4$ over a month & $\sim 3 \mathrm{E}-4$ over 8 months & 2E-4 over 2 years \\
\hline Co-seismic & $\begin{array}{l}\text { Clipped } \\
\text { if step > 5E-6 }\end{array}$ & $\sim 3 \mathrm{E}-6$ & $\sim 3 \mathrm{E}-5$ & $\sim 1 \mathrm{E}-4$ \\
\hline Pre-seismic & $\begin{array}{l}\text { Even if it exists, }<1 \mathrm{E}-8 \text { or } \\
\text { within } 10 \mathrm{~s} \text { before the } \\
\text { event }\end{array}$ & & & See text \\
\hline Post-seismic & Logarithmic & Logarithmic & - & Logarithmic \\
\hline Remarks & & $\begin{array}{l}\text { Strain change consistent } \\
\text { with: } \\
\text { - numerical modeling } \\
\text { - and seismic } \\
\text { - parameter change }\end{array}$ & $\begin{array}{l}\text { Semi 3-dimentional } \\
\text { strain monitoring with } \\
\text { a pair of strainmeters }\end{array}$ & \\
\hline
\end{tabular}

Evertson dilatometer with an effective sensitivity of $10^{-9}$. They monitored dilatation with a dot-recorder, and made fundamental findings:

- A significant coseismic step was followed by a large logarithmic postseismic strain.

- The magnitude of coseismic step was just as predicted by theory.

- Accelerating strain changes such as tertiary creeps in rock experiments were not observed even within source areas (less than $10^{-8}$ or within $10 \mathrm{~s}$ prior to an event even if it existed).
However, the dilatometer detected only dilatation. Zeroing was needed everyday because a strain change larger than 5 $\times 10^{-6}$ is clipped.

The Ishii strainmeter (e.g. Ishii et al., 1997a, 2002) is a borehole strainmeter detecting strain changes in diametric and borehole-axis directions. It amplifies the changes with up to forty times with a petal plate with well-designed slits so that the remnant works as cascaded levers. So, it is as sensitive as the Sacks-Evertson dilatometer, but much smaller in diameter, enabling us easier drilling and installation (see further details in Table 1). The Ishii strainmeter is sensitive enough to detect change as subtle as the Earth's tides, is stable over long 
periods for detecting tectonic crustal movement, and is being deployed widely in Japan to successfully measure dynamic movements.

As detailed in Table 1, we had attempted monitoring in South African gold mines, finding that it is also robust enough to monitor the largest strain changes in mines (Ishii et al., 1996, 1997b, 1998). Then, we could make a substantially highresolution monitoring with the latest data-recording-system of ISS International Ltd in this study. We used a 4-component Ishii borehole strainmeter to detect strain in three diametric directions and the borehole-axis direction. The strain we recorded at our study site is shown in Figure 2 and will be discussed here in detail. An Earth tide with an amplitude on the order of $10^{-8}$ can be clearly detected on weekends, when there is less mining activity. Figure 3 shows an example of Earth tide recordings two days prior to the M2 events, which is central to this study. Figure 3 also demonstrated that the strainmeter works well and produces reliable records.

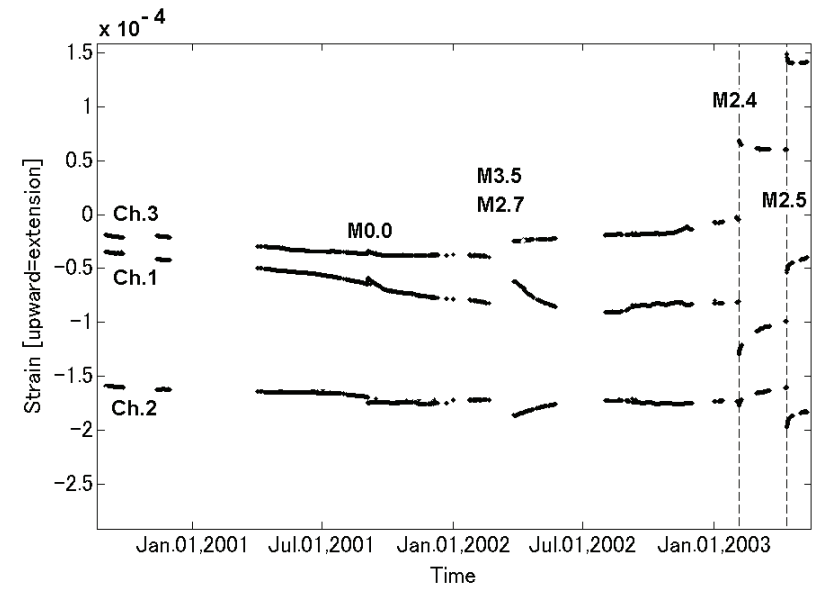

FIG. 2 Strain recordings over a few years (September 2000 - May 2003) at our study site. Extension is in the upward direction. The Ishii strainmeter successfully recorded strain change on the order of $10^{-4}$, associated with a series of $M>2$ events. Interruptions in recording were due to power failures or communication cable problems

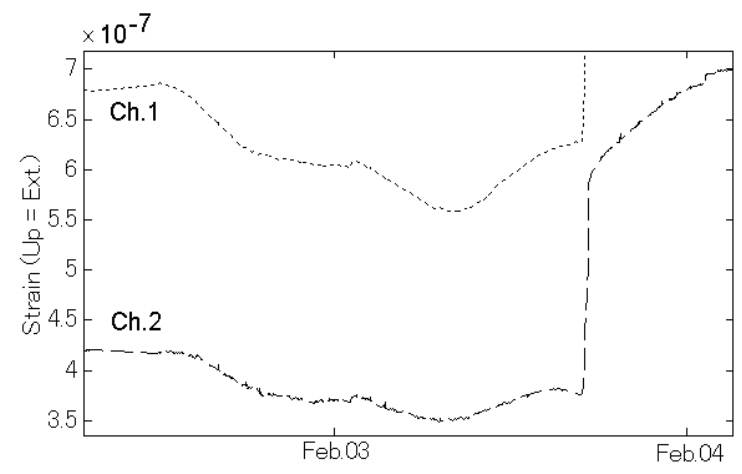

FIG. 3 A typical example of an Earth tide on a Sunday (Feb. 2, 2003), with reduced mining activity, compared to blasting-associated strain change on a Monday evening (Feb. 3, 2003). Strain steps due to blasting show logarithmic change. Polarity of Channel 2 is reversed to emphasize coherency
We drilled an NXC hole (92 mm diameter) with a dip of 15 degree from the sidewall at a distance several metres from an intersection of fault $\mathrm{T}$ and a crosscut tunnel (Figure 1). The drilled core was carefully checked to find the leastfractured installation location. The strainmeter was then installed at a depth of $14 \mathrm{~m}$, at a sufficient distance from fissure zones or stress concentration areas around the crosscut tunnel. The strainmeter was grouted with expanding cement, and the remainder of the hole was filled with ordinary cement nearly to the collar (Ishii et al., 2000, Ogasawara et al., 1999, 2001, and 2002).

Channel 1 was set vertically to detect strain in the direction of maximum principal stress at this site. Then, as schematically shown in Figure 4, slip-driving shear strain on the fault plane was monitored with a combination of Channels 1 and 3 , and strain normal to the fault plane with Channel 2.



(a) Before deformation

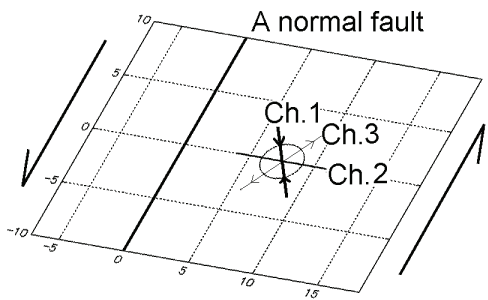

(b) After deformation without slip

FIG. 4 Schematic illustration (vertical section normal to a fault) explaining contraction and extension observed on each channel orthogonal to borehole axis. (a) and (b): before and after shear deformation in rockmass with the normal fault locked. During a stress-accumulation period, shear stress on the normal fault increases, letting Channel 1 contract and Channel 3 extend, with Channel 2 remaining constant

We modified a data acquisition system for a broadband seismometer (ISS International MS® with a 24-bit, 25-Hz A/D conversion) to continuously monitor strain change. The MS samples data at a frequency much higher than $25 \mathrm{~Hz}$ to decimate with a FIR digital filter with a non-causal artifact, which is discussed in Section 3.4. The MS chops the data into files with 2-minute periods, and send them to the surface central workstation. The ISS Run Time System at a central workstation catalogues and stores them in the same way as seismic data (e.g. Mendecki, 1997).

\subsection{Seismic Monitoring}

Seismic stations are equipped with geophones or accelerometers with an average spacing of several hundreds of metres, the nearest seismic station being located about $200 \mathrm{~m}$ from the strainmeter. The geophones and accelerometers are digitized, with frequencies of $2 \mathrm{kHz}$ and $15 \mathrm{kHz}$, respectively, which enables us to locate seismic events an accuracy of a few tens of metres. 


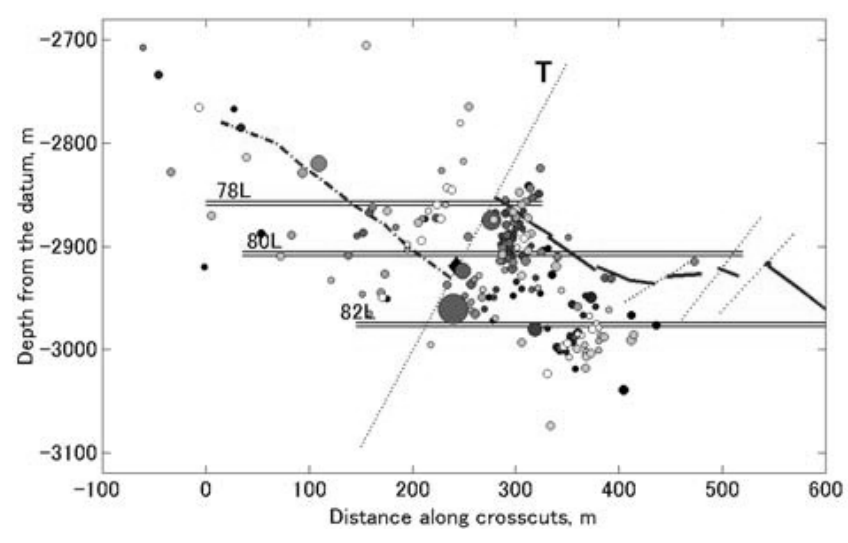

FIG. 5 Seismicity in February 2003 in vertical section normal to strikes of faults and reef shown in Figure 1. The largest event was M2.4 on 4 February, the smallest magnitude being about -1 . Seismicity evidently was associated with activity of fault $\mathrm{T}$ in Figure 1

\section{RESULTS}

\subsection{Secular Strain Change}

Figure 2 shows strain changes for a period starting September 2000, during which several significant earthquakes with $M>2$ occurred within about $100 \mathrm{~m}$ of the strainmeter. M3.5 and M2.7 events took place at a relatively greater distance in February 2002, but the associated changes were not successfully recorded because of communication cable problems. There are additional gaps in recording due to power failures or cable problems.

The magnitude of strain change was on the order of $10^{-4}$, which was recorded only within the seismogenic area. If we take a typical Young's modulus of $70 \mathrm{GPa}$ into account, then stress change corresponding to a $10^{-4}$ strain change is about $7 \mathrm{MPa}$, which is comparable to a typical seismic stress drop.

Channel 1 detects strain in a direction nearly parallel to the maximum principal stress and it detected contraction until the middle of 2002, suggesting an increase in maximum principal stress, after which Channel 3 started to show extension. Although Channel 1 values remained nearly constant after the middle of 2002, Channel 3 started to show extension in the middle of 2002, suggesting an increase in shear stress in the rockmass, as illustrated in Figure $4 \mathrm{~b}$. Meanwhile, Channel 2 , which corresponds to normal stress on the fault, remained nearly constant.

Channel 1 recovered to the level of September 2000, associated with two $M>2$ events in 2003, which are data central to this study. Channel 3 continued to show relaxation.

Post-seismic deformation wascharacterized by alogarithmic change with the time difference remaining constant from event to event. In addition, there were numerous minute strain steps followed by a logarithmic post-seismic change associated with many minor or later events not figured here.

\subsection{Seismicity in February and April 2003}

Figures 5 and 6 show the hypocentral distribution of seismicity in February and April 2003, respectively, superimposed on the vertical section in Figure 1 when events with $M>2$ took place. We should keep in mind that the epicentre location error is a few tens of metres and that the resolution in a direction perpendicular to the reef is relatively poorer. However, it is clear that the activity was located beneath the gold reef on the eastern side of Fault T; the activity in February was closer to the fault than the activity in April.



FIG. 6 Same as Fig 5, but shows seismicity in April. Seismicity was not on the fault $\mathrm{T}$, but was associated with an area where minor faults and a dyke were mapped

\subsection{A Several-day Period before Main Shocks}

Figures 7 and 8 show changes in strain and seismic parameters for a several-day period with $\mathrm{M}>2$ events prior to the main shocks for February and April 2003, respectively. As seen in Figures 7a and 8a, there is no preceding acceleration in strain comparable to the strain steps of the main shock.

In amplified recordings (Figure $7 \mathrm{~b}$ and $8 \mathrm{~b}$ ), there are sometimes unusual changes seen only in a single component (e.g. Channel 3 on 1 Feb., or Channel 1 on 10 Apr.), the reasons for which are unknown. Other than these, the changes show good coherency; in a further amplified strain profile (Figure 3), we can clearly see an Earth tide with good coherency, as a confirmation of data reliability. It should be emphasized that we can see extension in Channel 1, which corresponds to a relaxation in maximum principal stress. In the course of further changes, a series of small steps and logarithmic transients associated with smaller foreshocks (29 Jan.) and mining activity (3 Feb., 9 Apr. and 12 Apr.) are significant. Once again, no accelerations such as "time to failure" or tertiary creep are seen.

Although it is not easy to evaluate the reliability of the median of the Energy Index (van Aswegen and Butler 1993) for a period with few earthquakes, the Energy Index seemed to decrease prior to the main shock, when we also saw significant strain transients (3 Feb. or 9 Apr.).

\subsection{A Period less than Several Tens of Second before Main Shocks}

It is necessary to take a very close look at the final several tens of seconds prior to the main shocks (Figure 9ab and 10ab). Here we find an interesting contrast; the M2 in February was accompanied by many foreshocks of $M<1.6$ just prior to the main shock, whereas the M2 in April had no foreshocks. The onset of the main shock was abrupt in both recordings, with no acceleration in strain.

Figures $8 \mathrm{~cd}$ and 9cd show periods of the last few seconds. The non-causal effects of an FIR digital filter are seen prior to the onset of strain steps. Because of a mechanical after-effect of the strainmeter during the final M1 foreshock, we were unable to eliminate this artifact for February data. However, Takeuchi et al. (2003) successfully eliminated non-causal artifacts with a minimum phase filter (Scherbaum 2001) to observe the last 0.1-second period of April data (Figure 11). Once again, no acceleration was found. 

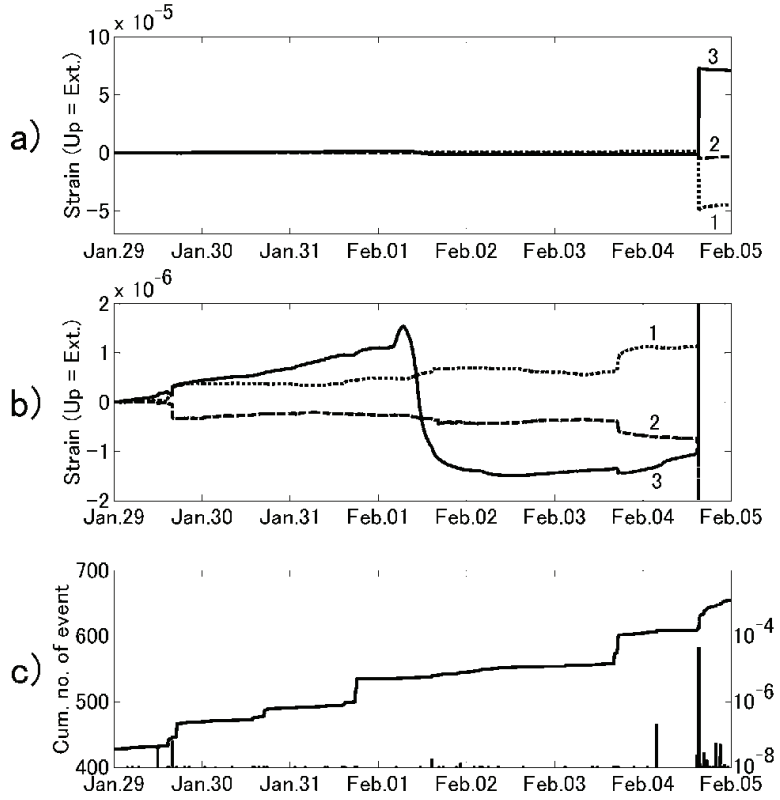

d)

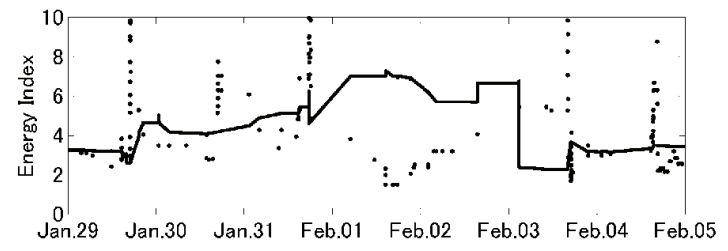

FIG. 7 Change in strain and seismic parameters over a severalday period for the February 2003 event. (a) strain, (b) strain amplified by a factor of 50 , (c) cumulative number of events (stairs) and expected strain steps (bars) and (d) Energy Index (moving 10-event median shown by a dot, moving "2-day or 5-event" median shown by a thick, solid line


d)

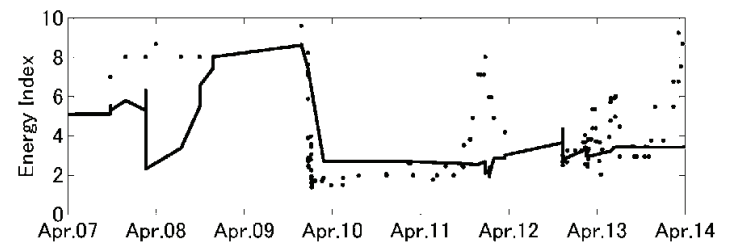

FIG. 8 Same as Figure 7 except data for April
4 February 2003

a)

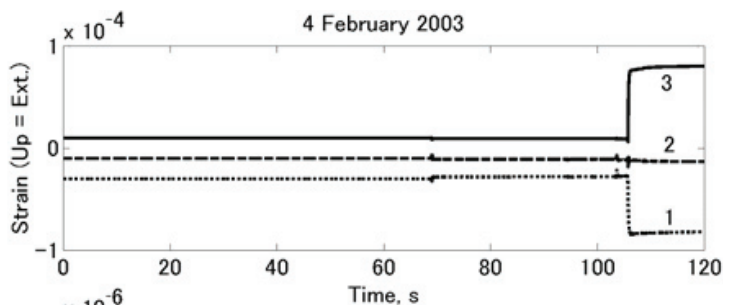

b)

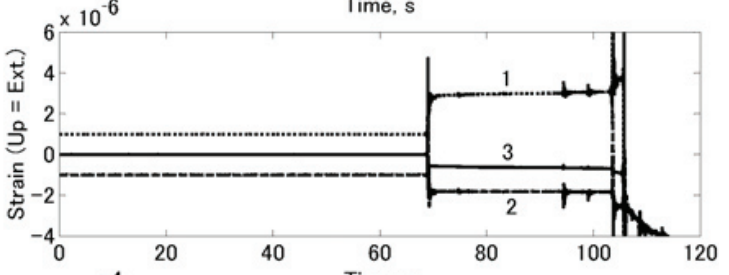

c)

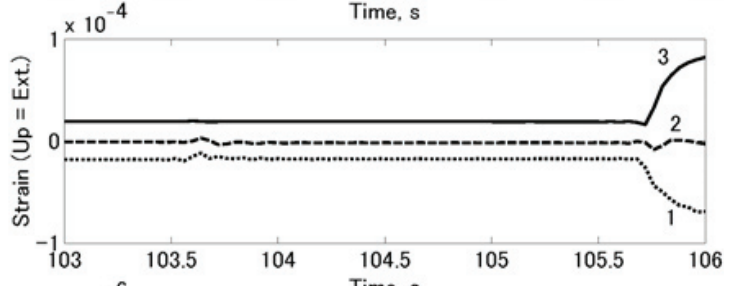

d)



FIG. 9 Closer look at strain recordings with onset of main shock. (a) a period of several tens of seconds, with (b) amplified by a factor of 50 . (c) the last-few-second period, with (d) amplified by a factor of 50



b)
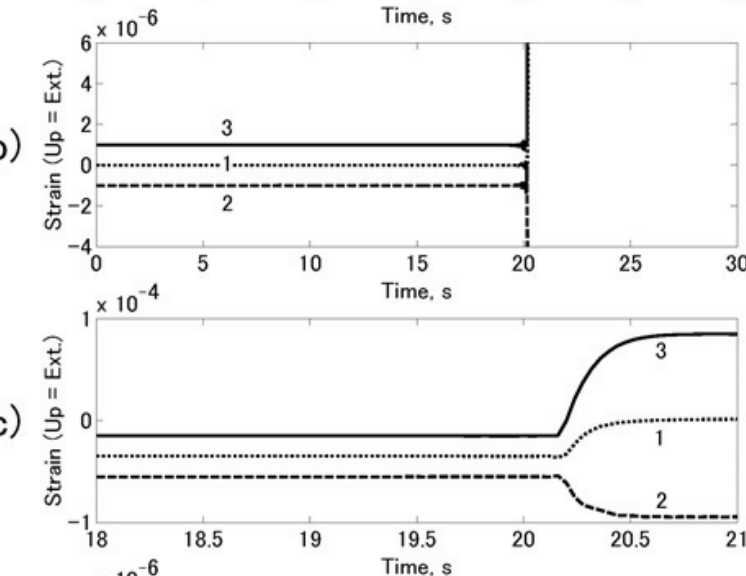

d)

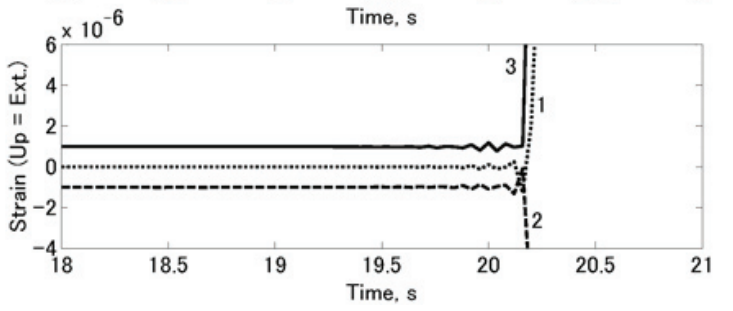

FIG. 10 Same as Figure 9, except April event is shown 


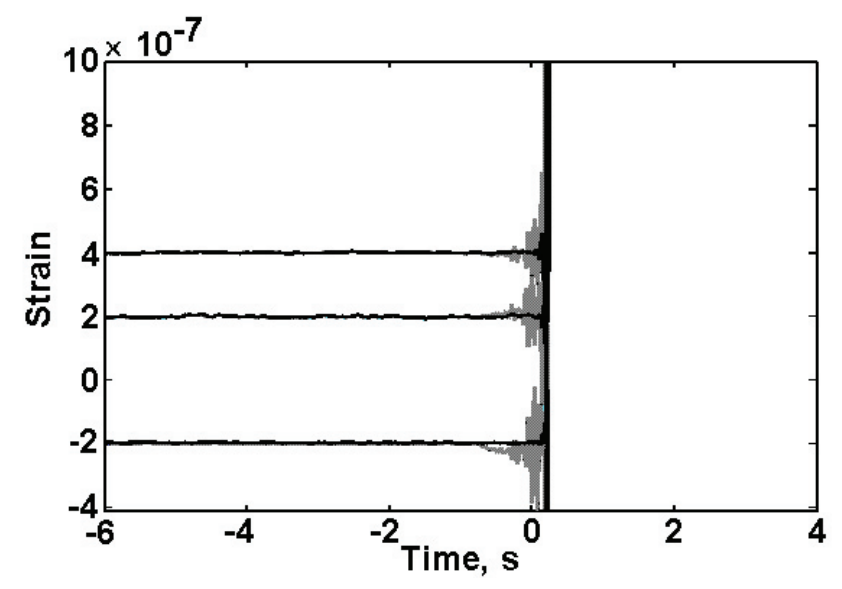

FIG. 11 The closest look at the onset of the April M2 event (after Takeuchi et al., 2004). Gray: original recordings with noncausal artifact, solid black line: artifacts eliminated with a minimum-phase filter

\subsection{Other Interesting Strain Changes}

In Figure 2, significant strain changes are clearly seen for a very small event with $\mathrm{M}=0.0$ in September 2001, when interesting strain transients were recorded, although not all were accompanied by seismic events (Takeuchi et al., 2002). We must look more closely at such phenomena to understand rockmass behaviour.

\section{CONCLUDING REMARKS}

We installed a sensitive, stable and robust strainmeter in a hypocentre area. Continuous 24-bit, 25- $\mathrm{Hz}$ monitoring over a few-year period enabled us to closely examine the seismogenic processes of an earthquake. We successfully monitored strain steps comparable to stress drop in a seismic source area, and closely examined strain change until the last $0.1 \mathrm{~s}$ prior to the main shock, with a resolution of $10^{-8}$. Monotonic relaxation of maximum principal strain on the order of about $10^{-6}$ per week was observed for a several-day period prior to the main shocks. However, no continuous acceleration that was a function of "time to failure" or tertiary creep was recorded in strain prior to the main shocks.

Such phenomena amount to less than $1 / 10,000$ of a coseismic step, if they exist. Our monitoring system had superior time-resolution and dynamic range compared to those used in earlier studies (e.g. McGarr et al., 1982), although our conclusions are the same. Concentrated foreshocks with significant steps and logarithmic transients were seen in one of two cases for a period of several tens of seconds. We need more such studies to elucidate the potential relationship between concentrated foreshocks and so-called acceleration in deformation prior to main shocks.

At the present time, we don't know if monotonic relaxation in principal strain is a real phenomenon related to the source areas of earthquakes. An array of multiple strainmeters will be crucial for pursuing the problem in the next phase of our study (Ogasawara et al., 2005).

A more-precise location of seismic events is also needed. We experimented with relative location methods for the current study site (Shimoda et al., 2004). The lack of a closer seismic station was a problem in the current study and will be resolved in the next phase of our work.

\section{ACKNOWLEDGMENTS}

We thank personnel at the Bambanani mine for facilitating our project. We are also grateful for personnel of ISS International Ltd, and Geohydroseis CC, especially Patrick Lenegan, Andrew Tsukudu, Hanno Hoogenboezem, Peter Mountfort, Jan Danilowicz, Paul Hewlet, Errol de Kock, Marie Gerenger, Jeanne Wall and Andre Rossouw for their technical support that greatly facilitated our project. This project was funded by Grants-in-aid from the Ministry of Education, Culture, Sports, Science and Technology, Japan (Nos. 10554019, 14403005, 14204040). We are also grateful to helpful comments by anonymous referees that improved the manuscript.

\section{REFERENCES}

Amadei, B. and Stephansson, O. (1997) Rock Stress and its Measurement. Chapman \& Hall, London, 490 pages.

Eden, D.J. (1995) Stress change monitoring in a dolorite dyke, Welkom, South Africa. ISS International Report. Welkom: ISS International.

Iio, Y. and Fukao, Y. (1992) Call for joining international experiment in South African gold mines. News Letter Seismol. Soc. Jpn. 3(6): pp. 8-9 (in Japanese)

Iio, Y. (1995a) Earthquake prediction in South African gold mines. Iwanami Science 65: pp. 279-281 (in Japanese).

Ishii, H. and The Research Group for Semi-controlled Earthquake Generation Experiment in South African Gold Mines (1996) Semi-controlled experiment in a gold mine in South Africa (5) - strain observation by borehole strain meters -. Abstracts. 1996 Japan Earth and Planetary Science Joint Meeting, pp. 429-429 (in Japanese).

Ishii, H., Yamauchi, T. and Kusumoto, F. (1997a) Development of high sensitivity bore hole strain meters and application for rock mechanics and earthquake prediction study. In Rock Stress Balkema, Rotterdam, pp. 253-258.

Ishii, H. and The Research Group for Semi-controlled Earthquake Generation Experiment in South African Gold Mines (1997b) Semi-controlled experiment in a gold mine in South Africa (10) - observation by borehole strain meter: long term strain variation related to mining strain. Abstracts. 1997 Japan Earth and Planetary Science Joint Meeting, pp. 168-168 (in Japanese).

Ishii, H., Ohkura, T. and The Research Group for Semi-controlled Earthquake Generation Experiment in South African Gold Mines (1998) Strain monitoring and earthquake generation in South African gold mine. Earth monthly 229, pp. 419-420 (in Japanese).

Ishii, H., Nakao, S., Ogasawara, H. and The Research Group for Semicontrolled Earthquake Generation Experiment in South African Gold Mines (2000) Continuous monitoring of strain by $25 \mathrm{~Hz} 24$ bit sampling using Ishii's borehole strainmeter on a hypocentral fault where an $\mathrm{M}>3$ event is expected - semi-controlled experiment in a gold mine in South Africa (25) - Abstracts. Seism. Soc. Jpn. 2, pp. A58-A58 (in Japanese)

Ishii, H., Yamauchi, T., Matsumoto, S., Hirata Y. and Nakao, S. (2002) Development of multi-component borehole instrument for earthquake prediction study, some observed example of precursory and coseismic phenomena relating to earthquake swarms and application of the instrument for rock mechanics. In Seismogenic Process Monitoring (ed. H. Ogasawara, T. Yanagidani and M. Ando) Balkema, Rotterdam, pp. 365-377.

Johnston, M.J.S. and Linde, A.T. (2002) Implications of crustal strain during conventional, slow, and silent earthquakes. In International Handbook of Earthquake Engineering Seismology, Volume 81A (IASPEI), 589-605.

McGarr, A. (1976) Dependence of magnitude statics on strain rate. Bull. Seism. Soc. Am. 66, pp. 33-44

McGarr, A. and Green, R.W.E. (1975) Measurement of tilt in a deep-level gold mine and its relation-ship to mining and Seismicity. Geophys. J. R. astr. Soc. 53, pp. 327-345.

McGarr, A. and Green, R.W.E. (1978) Microtremor sequences and tilting in a deep mine. Bull. Seis. Soc. Am. 68, pp. 1679-1697.

McGarr, A., Sacks, I.S., Linde, A.T., Spottiswoode, S.M. and Green, R.W.E. (1982) Coseismic and other short-term strain changes recorded with Sacks-Evertson strainmeters in a deep mine, South Africa. Geophys. J R. astr. Soc. 70, pp. 717-740.

Mendecki, A.J. (ed) (1997) Seismic Monitoring in Mines. Chapman and Hall, London, 262 pages.

Mendecki, A.J. (1993) Keynote address: real time quantitative seismology in mines. In Rockbursts and Seismicity in Mine (ed. R.P. Young) Balkema, Rotterdam, pp. 287-295.

Nicolaysen, L.O. (1992) International Semi-controlled experiment on seismic events: a review of the background and proposal. News Letter Seism. Soc. Jpn. 3(6), pp. 9-27. 
Ogasawara, H., Ishii, H., Nakao, S. and the Research Group for Semicontrolled Earthquake Generation Experiment in South African Deep Gold Mines (1999) An attempt of $10 \mathrm{~Hz}$ continuous 3-dimensional strain monitoring on a source fault in a South African deep gold mine where $\mathrm{M}=2$ event is promising. In Proceedings of the GSJ Workshop, Fault Rocks and Seismogenic Process - Deformation of Fault Materials: Field Observations, Laboratory Studies, and Modeling -, Geol. Surv. Japan Interim Report. EQ/99/1, pp. 81-84.

Ogasawara, H., Sato, S., Nishii, S., Sumitomo, N., Ishii, H., Iio, Y., Nakao, S. Ando, M., Takano, M., Nagai, N., Ohkura, T., Kawakata, H., Satoh, T., Kusunose, K., Cho, A., Mendecki, A., Cichowicz, A., Green, R.W.E. and Kataka, M.O. (2001) Semi-controlled seismogenic experiments in South African deep gold mines. In Proceedings 5th International Symposium on Rock-burst and Seismicity in Mines (G. van Aswegen, R.J Durrheim, W.D. Ortlepp), pp. 293-300.

Ogasawara, H. and the Research Group for Semi-controlled EarthquakeGeneration Experiment in South African Deep Gold Mines (2002) Review of semi-controlled earthquake-generation experi-ments in South African deep gold mines (1992-2001). In Seismogenic Process Monitoring (ed. H. Ogasawara, T. Yanagidani and M. Ando) Balkema, Rotterdam, pp. 119-150.

Ogasawara, H., Takeuchi, J., Shimoda, N., Nakatani, M., Kato, A., Iio, Y., Kawakata, H., Yamada, T., Yamauchi, T., Ishii, H., Satoh, T., Kusunose, K., Otsuki, K., Kita, S., Nakao S., Ward, A.K., McGill, R., Murphy, S.K., Mendecki, A.J., van Aswegen, G., and the Research Group for Semi-controlled Earthquake-generation Experiments in South African deep gold mines (2005) Multidisciplinary Monitoring of the Entire Life Span of an Earthquake in South African Gold Mines. Proceedings Rasim6. accepted.

Ryder, J.A. and Jager, A.J. (2002) A textbook on Rock Mechanics for Tabular Hard Rock Mines, SIMRAC, Johannesburg, 489 pages.

Scherbaum, F. (2001) Of Poles and Zeros. 2nd Edition. Kluwer Academic Publishers, Dordrecht, 268 pages.

Shimoda, N., Takeuchi, J., Ogasawara, H., Ishii, Nakao, S., Ando, M. and the Research Group for Semi-controlled Earthquake-Generation Experi-ment in South African Deep Gold Mines (2004) Strain change with M2 events within $100 \mathrm{~m}$ and an attempt for better location with double-difference method to discuss it, Abstracts. 2004 Japan Earth and Planetary Science Joint Meeting S044-P002.

Sumitomo, N. (1998) International joint research: semi-controlled earthquake generation experiment. Chikyu monthly. 229, pp. 391-394 (in Japanese).

Takeuchi, J., Ogasawara, H., Ishii, H., Ide, S., Mountfort, P., Cichowicz, A. and the Research Group for Semi-controlled Earthquake-generation Experiments in South African Deep Gold Mines (2002) Reduction of non-causal artifact of a data acquisition system for Ishii strainmeter at South African gold mines and logarithmic post-seismic movement, Abstracts 2002 Jpn Seismol. Soc. Fall Meeting, pp. P161-P161.

Takeuchi, J., Ogasawara, H., Ishii, H., Nakao, S., Ando, M., van Aswegen, G., Mendecki, A., Cichowicz, A., Mountfort P., Ide, S., Kawakata, H. and the Research Group for Semi-controlled Earthquake-generation Experiments in South African Deep Gold Mines (2003) Coseismic strain change of $10-4$ and $7 \times 10-5$ recorded with Ishii strainmeter by continuous $24 \mathrm{bit} 25 \mathrm{~Hz}$ monitoring on seismic fault of $\mathrm{M} \sim 3$ in deep gold mine, South Africa, Eos Trans. AGU, 84(46), Fall Meet. Suppl., Abstract S41C-0103.

van Aswegen, G. and Butler, A. (1993) Application of quantitative seismology in South African gold mines. In Rockbursts and Seismicity in Mine (ed R.P. Young) Balkema, Rotterdam, pp. 261-266. 